Japan. J. Breed., $34: 171 \sim 180$ (1984)

\title{
Re-examination on the Role of Vernalization and Photoperiod in the Flowering of Brassica Crops under Controlled Environment
}

\author{
Hiroshi Suge \\ Institute for Agricultural Research, \\ Tohoku University, Sendai 980
}

\begin{abstract}
Flowering response of 7 cultivars belonging to 3 different varieties of Brassica campestris were explored in their relation to vernalization, photoperiod and gibberellins (GAs) under controlled environment using growth cabinets. In 5 Japanese cultivars (Nozawana, Uzuki-Komatsuna, Shin-Santosai, Bansei-Mana and Shigatsu-Shirona) out of 7 ones tested, flowering did not occur under 8 hour photoperiods even though they had been vernalized (20 days) and received $\mathrm{GA}_{3}$ although it induced stem elongation. In those cultivars GAs are likely to play a direct role in the bolting but probably are not directly functional in initiating flowering. Two Chinese cultivars tested here were unique for their flowering responses. Tsai Hsin was a day neutral cultivar with low vernalization requirement; it flowered either under 24 and 8 hour photoperiods in both of vernalized and nonvernalized plants. Hong Tsai Tai was a typical long-day plant and it did not require vernalization under 24 hour photoperiod. On the other hand, vernalization substituted the long-day requirement since seed-vernalized plants flowered even under short-days. Application of $\mathrm{GA}_{3}$ induced the flowering in nonvernalized plants under 8 hour photoperiod and that of Ancymidol, an inhibitor of GA biosynthesis, inhibited the flowering of vernalized plants. In this cultivar, GAs seem to play some role not only in the bolting but also in the flowering itself.

KEY WORDS : Brassica campestris, vernalization, photoperiod, gibberellins, flowering, stem elongation.
\end{abstract}

\section{Introduction}

For the maximum flowering of Chinese cabbage, Brassica campestris var pekinensis, a combination of vernalization and long-day was required (LORENZ 1946). However, most of Japanese workers had a tendency to underestimate the role of day length in the flowering of Chinese cabbage (Sugryama 1943, Eguchi and Korde 1944, Yamasaki 1956, Shinohara 1959, Kagawa 1966) except recent studies done under controlled environmental conditions (Mori et al. 1979, Suge and Takahashi 1982).

Recently, Suge and Takahashi (1982) showed that some cultivars of Chinese cabbage did not flower under short-day conditions such as 8 hour photoperiod even though they had been seed-vernalized and received comparatively large amounts of $\mathrm{GA}_{3}$ or $\mathrm{GA}_{7}$ after the vernalization.

In this study, the role of vernalization and photoperiod in the flowering of other Brassica crops was explored under controlled environment in growth cabinets. GA relationships in the flowering response were also studied.

Other than Chinese cabbage, no data are available on the flowering response under controlled environmental conditions in Brassica crops.

\section{Materials and Methods}

First experiment: Seven cultivars of Brassica campestris having different vernalization requirement were selected as follows based on the result of the preliminary test.

Received September 15, 1983 
1. B. campestris var chinensis cv. Hong Tsai Tai (紅菜苔)

2. B. campestris var chinensis cv. Tsai Hsin (菜心)

3. B. campestris var rapifera cv. Nozawana (野沢菜)

4. B. campestris var rapifera cv. Uzuki-Komatsuna (卯月小松菜)

5. B. campestris var pekinensis cv. Shin-Santosai (新山東菜)

6. B. campestris var pekinensis cv. Bansei-Mana (晚生真莱)

7. B. campestris var chinensis cv. Shigatsu-Shirona（四月しろ菜）

Seeds of 7 cultivars were germinated at room temperature for 2 days in the water contained in Petri dishes, and the germinating seeds were vernalized at $5{ }^{\circ} \mathrm{C}$ for 20 days. Nonvernalized (contol) seeds were soaked in dishes at room temperature for 2 days just prior to the end of vernalization, thus providing the seedlings of approximately the same size and appearance as the vernalized ones. Both lots of seedlings were planted in plastic containers filled with a 1:1 mixture of sand and vermiculite, and grown in the growth cabinets (Koito KG type) under 8 or 24 hour photoperiod. The light source consisted of twenty-two 80 watt fluorescent lamps (Toshiba), nine 400 watt extra high pressure mercury lamps (metal-haloid, "Yoko", Toshiba) and twelve 200 watt refractor lamps (Toshiba), providing about 15,000 lux at the plant level. Temperature was controlled at $23^{\circ} \mathrm{C}$ during the light and at $18^{\circ} \mathrm{C}$ during the dark period. Same temperature change was also adopted even in 24 hour photoperiod coincided with that of 8 hour photoperiod.

Five days after the transfer the nonvernalized plants were divided into 2 groups each consisting 10-20 plants. A $20 \mathrm{ml}$ of $10 \mathrm{ppm} \mathrm{GA}_{3}$ solution was sprayed to run off 5 times at 2 days interval. The dates of boting, flower bud appearance and anthesis and the stem height and the number of leaves per plant at anthesis were recorded in all the experiments. The experiments were stopped 70 days after transplanting and the shoot apexes of the plants that had not yet reached the stage of bud appearance were examined under a binocular microscope. All plots consisted of more than 10 plants.

Second experiment: Further detailed experiment was done using 2 Chinese cultivars of B.campestris var chinensis, Hong Tsai Tai and Tsai Hsin since they were found to respond to $\mathrm{GA}_{3}$ quite differently in the first experiment. Experimental procedures were almost the same as those shown in the first experiment except that $\alpha$-cyclopropyl$\alpha$-(4-methoxyphenyl)-5-pyrimidine methanol (Ancymidol), an inhibitor of GA biosynthesis, was used.

At the necessary time, $20 \mathrm{ml}$ of a $0.5 \mathrm{~m} \mu \mathrm{M}$ Ancymidol was applied to the soil of each pot 2 days after the planting.

The experiments were stopped 90 days after the start of the experiment. In the second experiment, plants were grown under only 8 hour photoperiod at $25 / 20^{\circ} \mathrm{C}$, day/ night temperature. All plots consisted of more than 10 plants.

\section{Results}

First experiment: Vernalization resulted in the 100\% flowering of 4 cultivars out of 7 ones tested under long-days, while 3 cultivars did not reach 100\% flowering although 
vernalization increased percent of flowering plant evidently and decreased the number of days to flower bud appearance, number of days to first anthsis and number of leaves at anthesis. This may indicate that 20 days vernalization was not sufficient to satisfy low temperature requirement in those 3 cultivars, Shin-Santosai, Bansei-Mana and Shigatsu-Shirona (Table 1).

Under short-days, no flowering was detected, except 2 Chinese cutivars, Tsai Hsin and Hong Tsai Tai, even in the plants that had been vernalized and received GA treatment. Except those 2 Chinese cultivars, neither the nonvernalized plants nor the vernalized ones grown under short-days, with or without $\mathrm{GA}_{3}$, flowered, although $\mathrm{GA}_{3}$ : caused stem elongation in all the plants (Table 1 ).

With Hong Tsai Tai, $\mathrm{GA}_{3}$ induced flowering in nonvernalized plants even under shortdays although vernalized plants flowered under the same conditions without $\mathrm{GA}_{3}$ (Table 1).

Contrary to Hong Tsai Tai, Tsai Hsin flowered under short-days without vernalization and $\mathrm{GA}_{3}$. $\mathrm{GA}_{3}$ promoted the appearance of flower buds and first anthesis, however, the number of leaves at anthesis was almost the same between control and $\mathrm{GA}_{3}$-treated plants (Table 1).

Second experiment: With Tsai Hsin, the application of Ancymidol after seed vernalization reduced the stem height, however, resulted in flowering in nonvernalized plants. as well as in vernalized ones. The reduction of stem length was almost restored by the application of $\mathrm{GA}_{3}$ in nonvernalized plants although $\mathrm{GA}_{3}$ did not restore the reduction of stem height in vernalized plants, probably due to the very short growth duration in the latter. Ancymidol gave almost no effect on the number of leaves at. anthesis (Tables 2 and 3, Fig. 1).

On the other hand, the flowering response was quite different with the cultivar Hong Tsai Tai. Vernalization treatment of seeds substituted the long-day requirement; vernalized plant flowered even under short-days whereas no flower formation was detected. in nonvernalized plants under short-days. Nonvernalized plants remained in vegetative conditions under'short-days, however the application of $\mathrm{GA}_{3}$ induced the stem elongation and flowering in those plants. $\mathrm{GA}_{3}$ also induced stem elongation and flowering even in nonvernalized plants to which. Ancymidol had been applied. The application of Ancymidol to vernalized plants inhibited the flowering; half of the Ancymidol-treated plants did not produce flower bud until the end of the experiment and remained in vegetative conditions. Half of them produced flower buds and flowered finally, however, the appearance of flower buds delayed greatly when compared with the plants that: had not received Ancymidol treatment. Further application of $\mathrm{GA}_{3}$ to the plants which had received Ancymidol treatment again restored 100\% flowering (Tables 2 and 3, Fig. 2).

\section{Discussion}

Low temperature (vernalization) and long-day are the main causal factors for the induction of flowering in winter annual Brassica crops. Other than Chinese cabbage (Suge and Takahashi 1982), however, data reported are fragmentary and no detailed 


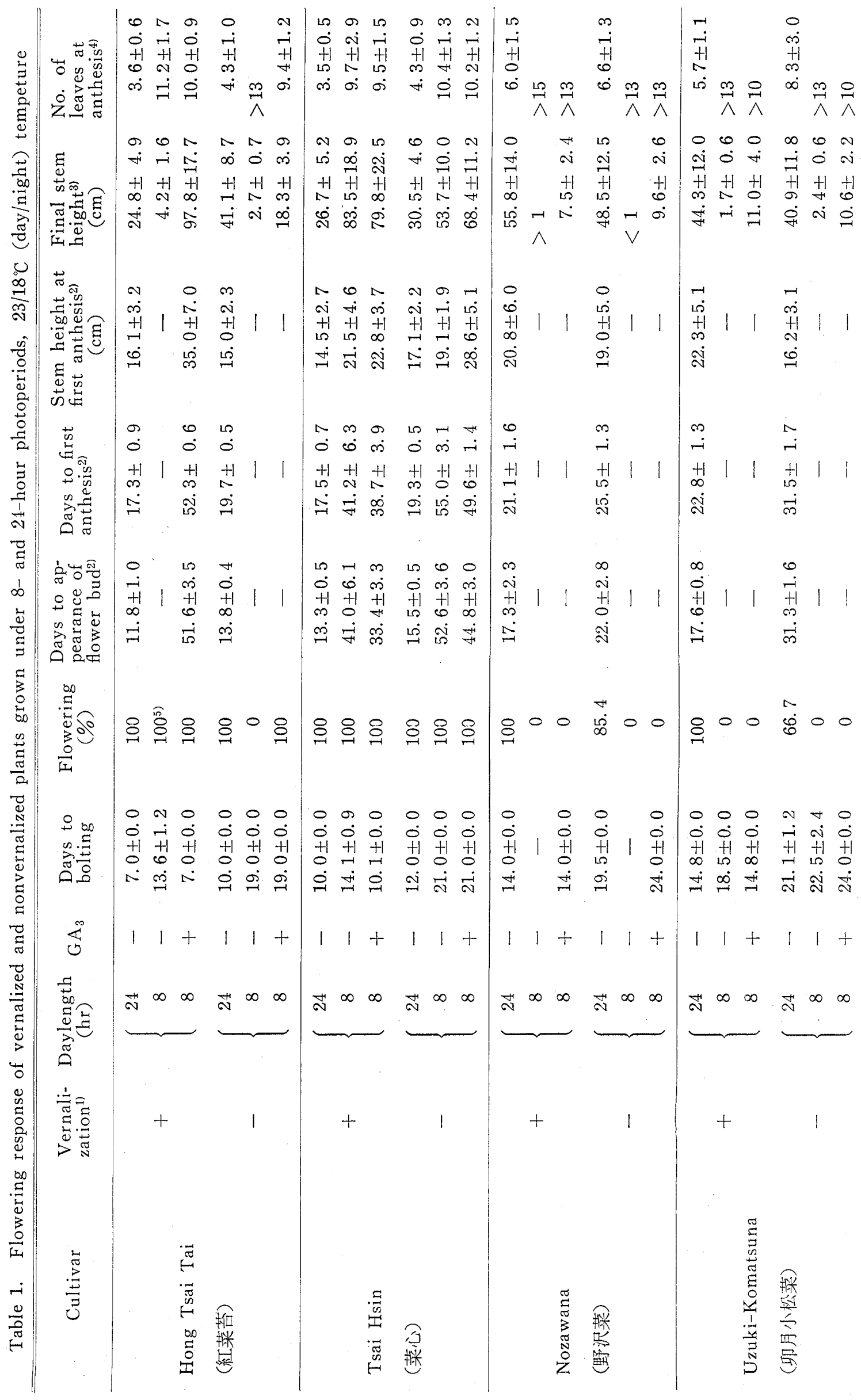




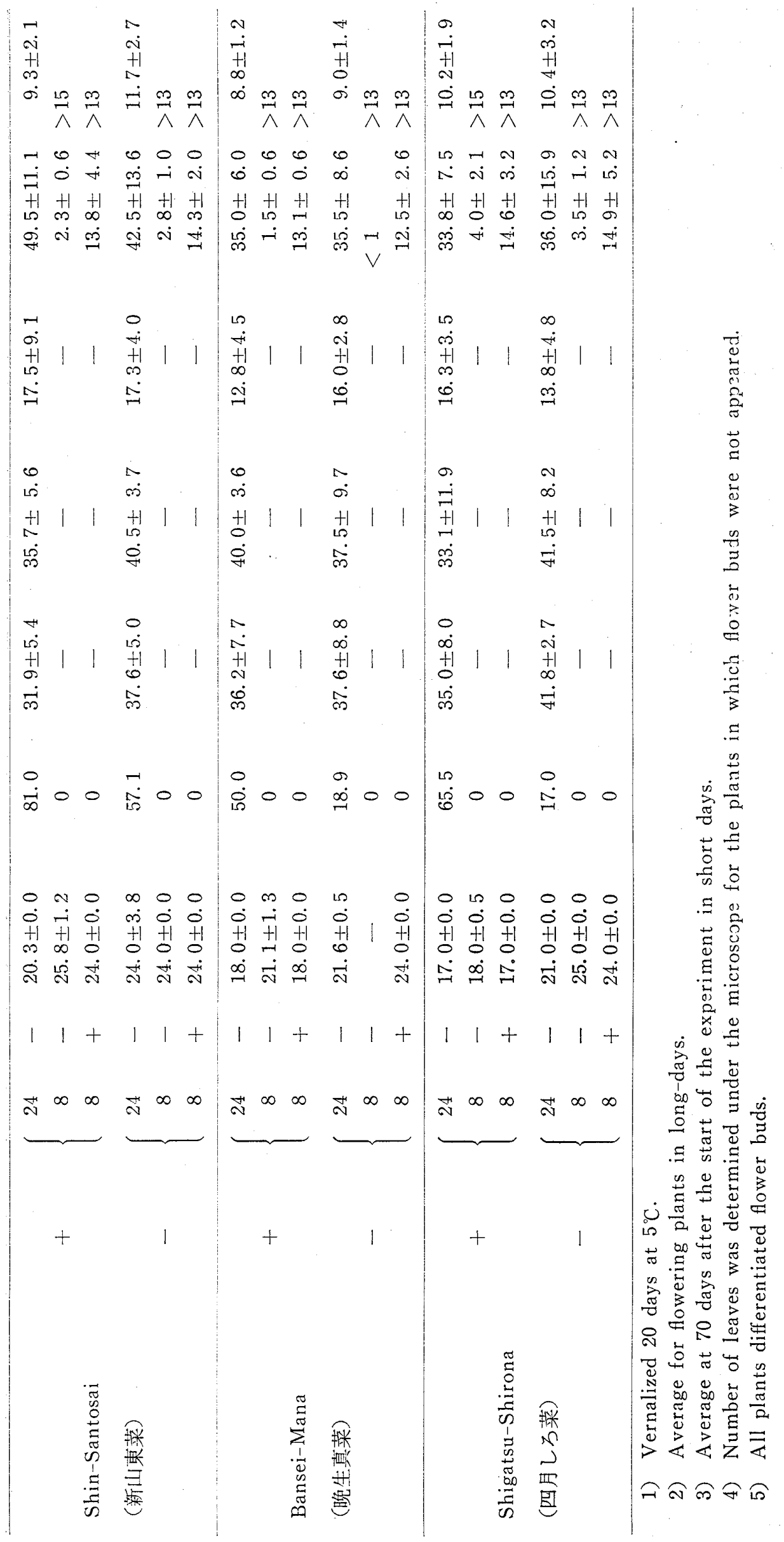


Table 2. Effect of $\mathrm{GA}_{3}$ and Ancymidol applied after seed vernalization on the stem elongation of 2 different cultivars of Brassica campestris var chinensis under 8 hour photoperiod and $25 / 20^{\circ} \mathrm{C}$ (day/night) temperature

\begin{tabular}{|c|c|c|c|c|c|c|c|c|c|}
\hline Cultivar & $\begin{array}{l}\text { Vernali- } \\
\text { zation } 1)\end{array}$ & $\begin{array}{l}\text { Ancy- } \\
\text { mido }^{2)} \\
(0.5 \\
\text { mM) }\end{array}$ & $\mathrm{GA}$ & $\begin{array}{l}\text { GA } \\
\text { plant/ } \\
\text { applica- } \\
\text { tion } \\
(\mu \mathrm{g})\end{array}$ & $\begin{array}{l}\text { Total } \\
\text { GA } \\
(\mu g)\end{array}$ & Bolting & $\begin{array}{l}\text { No of days } \\
\text { to bolting }\end{array}$ & $\begin{array}{l}\text { Stem } \\
\text { height } \\
\text { at first } \\
\text { anthesis } \\
\quad(\mathrm{cm})\end{array}$ & $\begin{array}{l}\text { Final } \\
\text { stem } \\
\text { height } \\
\quad(\mathrm{cm})\end{array}$ \\
\hline \multirow{8}{*}{$\begin{array}{l}\text { Tsai Hsin } \\
\text { (菜心) }\end{array}$} & \multirow{4}{*}{+} & \multirow{2}{*}{$\int-$} & - & 0 & 0 & 100 & $6.0 \pm 0.0$ & $19.6 \pm 1.8$ & $45.8 \pm 8.4$ \\
\hline & & & + & 5 & 15 & 100 & $6.0 \pm 0.0$ & $20.0 \pm 1.9$ & $42.8 \pm 9.0$ \\
\hline & & \multirow{2}{*}{+} & $\int-$ & 0 & 0 & 100 & - & $6.4 \pm 2.0$ & $17.9 \pm 4.2$ \\
\hline & & & + & 5 & 15 & 100 & $12.0 \pm 0.0$ & $13.2 \pm 2.8$ & $20.7 \pm 5.4$ \\
\hline & \multirow{4}{*}{ - } & \multirow{2}{*}{$\int-$} & $\int-$ & 0 & 0 & 100 & $26.4 \pm 0.8$ & $24.0 \pm 5.8$ & $66.8 \pm 15.9$ \\
\hline & & & $1+$ & 5 & 15 & 100 & $21.1 \pm 0.9$ & $25.4 \pm 4.2$ & $60.0 \pm 12.4$ \\
\hline & & \multirow{2}{*}{+} & $1-$ & 0 & 0 & 100 & - & $11.3 \pm 2.4$ & $25.1 \pm 7.3$ \\
\hline & & & + & 5 & 15 & 100 & 12.0 上 0.0 & $25.8 \pm 6.5$ & $64.1 \pm 10.0$ \\
\hline \multirow{9}{*}{$\begin{array}{l}\text { Hong Tsai } \\
\text { (紅菜苦) }\end{array}$} & \multirow{5}{*}{ Tai } & \multirow{2}{*}{$\int-$} & - & 0 & 0 & 100 & $6.0 \pm 0.0$ & $23.5 \pm 6.9$ & $57.0 \pm 17.4$ \\
\hline & & & + & 5 & 15 & 100 & $6.0 \pm 0.0$ & $31.0 \pm 6.9$ & $54.2 \pm 14.3$ \\
\hline & & \multirow{3}{*}{+} & & 0 & & & $51.1 \pm 18.1$ & $24.4 \pm 10.0$ & $70.0 \pm 22.3$ \\
\hline & & & & 0 & 0 & 50 & - & - & $1.8 \pm 0.9$ \\
\hline & & & + & 5 & 15 & 100 & $12.0 \pm 0.0$ & $23.0 \pm 0.0$ & $41.7 \pm 15.1$ \\
\hline & \multirow{4}{*}{-} & \multirow{2}{*}{-} & - & 0 & 0 & 0 & - & - & $2.9 \pm 0.6$ \\
\hline & & & + & 20 & 260 & 100 & $15.9 \pm 0.3$ & $37.0 \pm 7.3$ & $38.3 \pm 22.1$ \\
\hline & & \multirow{2}{*}{+} & 一 & 0 & 0 & 0 & - & $\ldots$ & $1.0 \pm 0.2$ \\
\hline & & & + & 20 & 260 & 100 & $20.0 \pm 1.1$ & $43.1 \pm 11.7$ & $73.2 \pm 12.4$ \\
\hline
\end{tabular}

1) Vernalized 35 days at $5^{\circ} \mathrm{C}$.

2) Ancymidol $(0.5 \mathrm{mM})$ was applied in the rate of $10 \mathrm{ml} /$ pot.

3) Average on flowering plants.

experiment was conducted under controlled environments using growth cabinets. As. for the Chinese cabbage, Suge and Takahashi (1982) studied the role of GAs in stem elongation and flowering in their relation to vernalization and photoperiod. They found that $\mathrm{GA}_{3}, 2,200 \mu \mathrm{g}$ in total, was not able to induce flowering in nonvernalized plant grown under 8 hour photoperiod in 4 different cultivars out of 6 ones tested, but $560 \mu \mathrm{g} \mathrm{GA}_{3}$ raised percentages of flowering in the vernalized plant that flowered under 8 hour photoperiod which varied from 0 to $30.0,33.3$ and $58.8 \%$ depending cultivars. In a cultivar, Harumaki-Grokuwase, all the plants remained in vegetative conditions under 8 hour photoperiod even though they had been vernalized 20 days and received $560 \mu \mathrm{g} \mathrm{GA}_{3}$ in total, although $\mathrm{GA}_{3}$ induced their stem elongation.

GA content of vernalized seedlings increased within the first 3 days after they were trasferred from short-day to long-day conditions. Bolting was inhibited slightly by Ancymidol applied during vernalization; it was almost completely inhibited in case Ancymidol was applied after seed vernalization. The experiment revealed that Ancymidol actually reduced GA content. Ancymidol, however, had essentially no effect on flowering. Suge and Takahashi (1982) concluded that GAs are likely to play a direct role in the bolting of Chinese cabbage, but probably are not directly functional in initiating flowering. This is also the case in a Japanese cultivar of radish (Suge and Rappaport 1968).

Flowering responses of various cultivars tested this time resembled fundamentally to those of Chinese cabbage (Suge and TAKAhashi 1982) although several cultivars were 
Table 3. Effect of $\mathrm{GA}_{3}$ and Ancymidol applied after seed vernalization on the flowering of 2 different cultivars of Brassica campestris var chinensis under 8 hour photoperiod and $25 / 20^{\circ} \mathrm{C}$ (day/night) temperature

\begin{tabular}{|c|c|c|c|c|c|c|c|c|c|}
\hline Cultivar & $\begin{array}{l}\text { Vernli- } \\
\text { zation } 1)\end{array}$ & $\begin{array}{l}\text { Ancy- } \\
\text { midol }^{2)} \\
(0.5 \\
\text { mM) }\end{array}$ & GA & $\begin{array}{l}\text { GA } \\
\text { plant/ } \\
\text { applica- } \\
\text { tion } \\
(\mu \mathrm{g})\end{array}$ & $\begin{array}{l}\text { Total } \\
\text { GA } \\
(\mu \mathrm{g})\end{array}$ & $\begin{array}{l}\text { Flow- } \\
\text { ering } \\
(\%)\end{array}$ & $\begin{array}{l}\text { Days to ap- } \\
\text { pearance of } \\
\text { flower bud }\end{array}$ & $\begin{array}{l}\text { Days to } \\
\text { first } \\
\text { anthesis }\end{array}$ & $\begin{array}{l}\text { No. of } \\
\text { leaves at } \\
\text { anthesis }\end{array}$ \\
\hline \multirow{8}{*}{$\begin{array}{l}\text { Tsai Hsin } \\
\text { (菜心) }\end{array}$} & \multirow{4}{*}{+} & \multirow{2}{*}{-} & - & 0 & 0 & 100 & $13.0 \pm 0.0$ & $21.2 \pm 1.0$ & $5.3 \pm 1.2$ \\
\hline & & & + & 5 & 15 & 100 & $13.0 \pm 0.0$ & $20.5 \pm 0.7$ & $5.6 \pm 1.3$ \\
\hline & & \multirow{2}{*}{+} & - & 0 & 0 & 100 & $13.0 \pm 0.0$ & $31.7 \pm 4.8$ & $4.7 \pm 0.8$ \\
\hline & & & + & 5 & 15 & 100 & $13.0 \pm 0.0$ & $24.3 \pm 3.6$ & $4.4 \pm 0.9$ \\
\hline & \multirow{4}{*}{-} & \multirow{2}{*}{-} & - & 0 & 0 & 100 & $50.2 \pm 2.3$ & $59.4 \pm 4.2$ & $14.0 \pm 1.9$ \\
\hline & & & + & 5 & 15 & 100 & $33.6 \pm 2.0$ & $44.3 \pm 4.2$ & $12.1 \pm 1.4$ \\
\hline & & \multirow{2}{*}{+} & - & 0 & 0 & 100 & $53.2 \pm 6.7$ & $64.9 \pm 8.3$ & $12.5 \pm 2.1$ \\
\hline & & & + & 5 & 15 & 100 & $34.9 \pm 0.6$ & $53.3 \pm 5.5$ & $12.6 \pm 1.7$ \\
\hline \multirow{9}{*}{$\begin{array}{l}\text { Hong Tsai } \\
\text { (紅菜苔) }\end{array}$} & \multirow[b]{4}{*}{ Tai } & \multirow{2}{*}{$1-$} & - & 0 & 0 & 100 & $22.8 \pm 4.3$ & $38.4 \pm 8.5$ & $7.6 \pm 2.7$ \\
\hline & & & + & 5 & 15 & 100 & $19.5 \pm 2.6$ & $30.8 \pm 2.8$ & $6.3 \pm 1.3$ \\
\hline & & & - & 0 & 0 & 50 & $71.3 \pm 18.2$ & $82.3 \pm 7.3$ & $13.0 \pm 2.2$ \\
\hline & & + & & & & & 一 & - & $>15$ \\
\hline & & & + & 5 & 15 & 100 & $26.6 \pm 5.5$ & $41.3 \pm 6.0$ & $6.5 \pm 1.6$ \\
\hline & \multirow{4}{*}{-} & \multirow{2}{*}{-} & 一 & 0 & 0 & 0 & - & - & $>15$ \\
\hline & & & + & 20 & 260 & 100 & $49.5 \pm 4.0$ & $70.5 \pm 12.4$ & $9.2 \pm 1.0$ \\
\hline & & \multirow{2}{*}{+} & - & 0 & 0 & 0 & -- & - & $>15$ \\
\hline & & & + & 20 & 260 & 100 & $68.3 \pm 4.9$ & $86.3 \pm 7.8$ & 11. $4 \pm 2.3$ \\
\hline
\end{tabular}

1) Vernalized 35 days at $5^{\circ} \mathrm{C}$ 2) Ancymidol $(0.5 \mathrm{mM})$ was applied in the rate of $10 \mathrm{ml} /$ pot.

3) Average on flowering plants. 4) Number of leaves was determined under microscope for the plants in which flower buds were not appeared.

found to have more low temperature requirement since 20 days vernalization was not sufficient to induce 100\% flowering even under long-days, whereas 6 cultivars of Chinese cabbage tested by Suge and TAkAhashi (1982) all flowered under long-days with 20 days vernalization.

However, among 7 cultivars tested here, 2 Chinese cultivars, Hong Tsai Tai and Tsai Hsin, were somewhat different in their flowering responses from other 5 Japanese cultivars, may be due to their low latitudinal origin of $30^{\circ} \mathrm{N}$ and less than $25^{\circ} \mathrm{N}$ respectively. Shinohara (1980) suggested the importance of photoperiod in the flowering of Brassica crops in the subtropics and tropics.

Five Japanese cultivars remained in vegetative conditions under short-days even though they had been seed-vernalized and received $\mathrm{GA}_{3}$, although $\mathrm{GA}_{3}$ induced stem elongation. This is almost the same with a Chinese cabbage cultivar, Harumaki-Gokuwase (Suge and TAKAhashi 1982).

Tsai Hsin was a day-neutral cultivar since it flowered under short-days without vernalization. Vernalization treatment of seeds was only slightly effective to promote flowering, thus the requirement for low temperature may exist also slightly in this cultivar.

On the other hand, flowering response of Hong Tsai Tai is interesting. The cultivar also has almost no low temperature requirement since the number of leaves at anthesis 


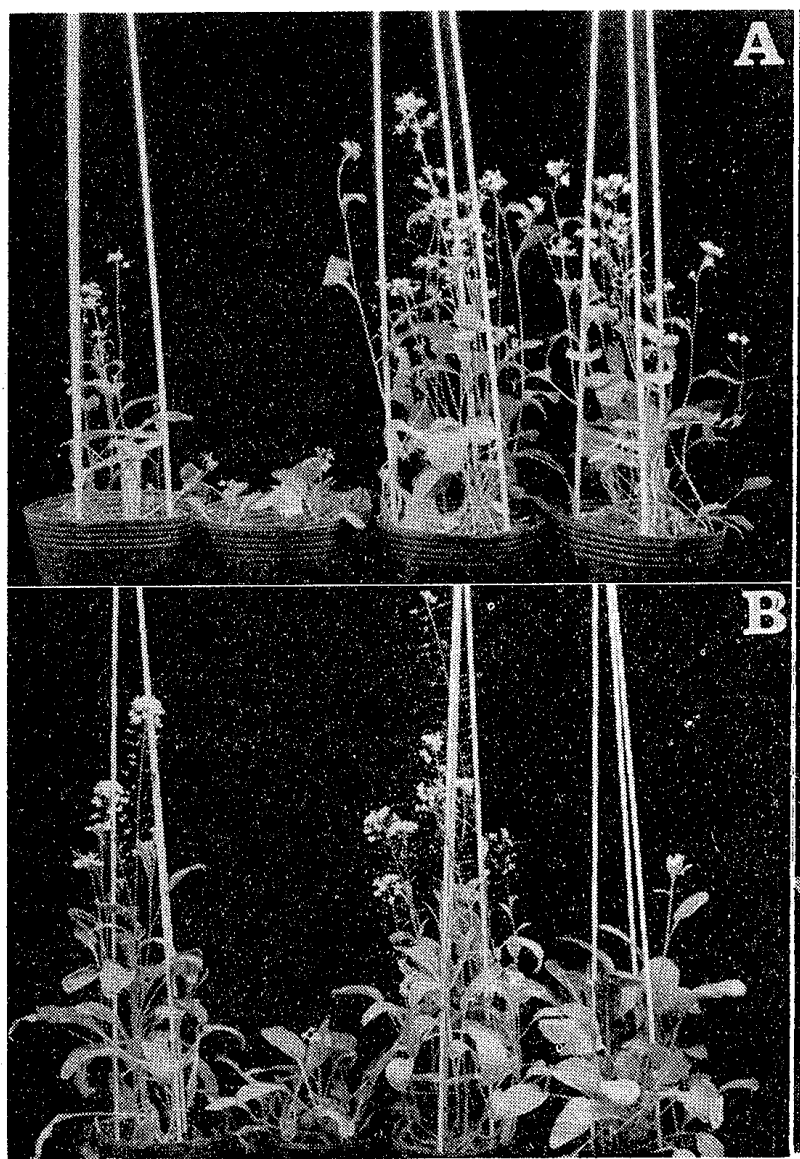

Fig. 1. The response of Tsai $\mathrm{H}$ sin to $\mathrm{GA}_{3}$ and Ancymidol under the condition of 8 hour photoperiod and $25 / 20^{\circ} \mathrm{C}$, day/night temperature. From right to left, Control, $\mathrm{GA}_{3}$-treated, Ancymidol-treated and Ancymidol and $\mathrm{GA}_{3}$-treated. $\mathrm{A}$ and $B$ indicate vernalized and nonvernalized plants, respectively. Note the flowering in Ancymidol-treated plants either in vernalized (A) and nonvernalized (B) plot. Photographs were taken at 28 days (A) and 53 (B) days after the start of the experiments.

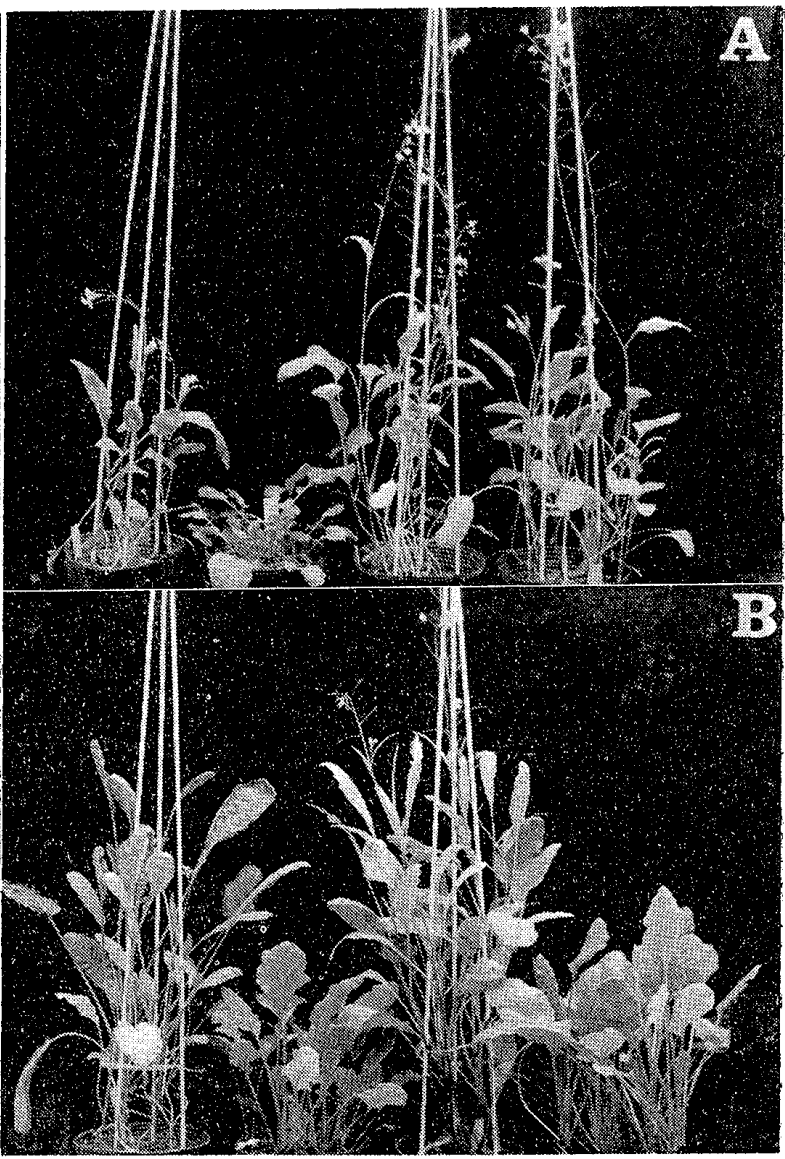

Fig. 2. The response of Hong Tsai Tai to $\mathrm{GA}_{3}$ and Ancymidol under the condition of 8 hour photoperiod and $25 / 20$ ${ }^{\circ} \mathrm{C}$, day/night temperature. From right to left, Control, $\mathrm{GA}_{3}$-treated, Ancymidol-treated and Ancymidol and $\mathrm{GA}_{3}-$ treated. $A$ and $B$ indicate vernalized and nonvernalized plants, respectively. Note the inhibition of flowering in Ancymidol-treated plants in vernalized plot (A) and the induction of flowering in $\mathrm{GA}_{3}$-treated plants in nonvernalized plot (B). Photographs were taken at 43 days (A) and 70 days (B) after the start of the experiments.

were 3.6 and 4.3 for vernalized and nonvernalized plants under long-days respectively. However, this was a typical long-day plant since it could not flower under short-day in nonvernalized plants. $\mathrm{GA}_{3}$ could substitute this long-day requirement. With other Japanese cultivars tested here, $\mathrm{GA}_{3}$ could not substitute their long-day requirement because $\mathrm{GA}_{3}$ could not induce flowering even in vernalized plants grown under short-days although it promoted stem elongation as mentioned above.

Thus, contrary to Chinese cabbage or other Japanese cultivars of B. campestris, GAs may play some significant role not only in the stem elongation but also in the flowering. itself in Hong Tsai Tai. The fact that the application of Ancymidol, an inhibitor of GA biosynthesis, to vernalized plants reduced the flowering plants also supports the 
view that endogenous GAs may have some role in the flowering of this cultivar.

The author would like thank to Dr. M. Hirao of Mikado Seed Grower's Co. Ltd. and Dr.K. Hinata of Tohoku University for their kind suggestions on the taxonomy of Brassica crops. The present work was supported partially by a grant-in-aid from the Ministry of Agriculture, Forestry and Fishery, the Japanese Government.

\section{Literature cited}

EGUCHI, T. and M. KOIDE 1944. On the relationship between seeding time and flower bud differentiation and vernalization in Japanese radish and Brassica vegetable crops. Jour. Japan. Soc. Hort. Sci. $15: 1 \sim 27$.

EGUCHI, T., A. KAgAWA and T. MATSUMURA 1960. Studies on the seed production in Chinese cabbage (Brassica pekinensis Rupr.) I. On the flower bud differentiation in Chinese cabbage. Bull. Natl. Inst. Agric. Sci. Ser. E $8: 49 \sim 58$.

KAGAWA, A. 1966. Studies on the effect of thermo-induction in floral initiation of chinese cabbage. Bull. Fac. Agric. Gifu Univ. 22:29 39.

LORENZ, O. A. 1946. Response of Chinese cabbage to temperature and photoperiod. Proc. Amer. Soc. Hort. Sci. $47: 309 \sim 319$.

MORI, K., H. EGUCHI and T. MATSUI 1979. Mathematical model of flower stalk development in Chinese cabbage affected by low temperature and photoperiod. Environ. Control in Biol. $17: 17 \sim 26$.

SHINOHARA, S. 1959. Genecological studies on the phasic development of flowering centering on the Cruciferous crops, especially on the role of vernalization on ripening seeds. Technical Bull. Shizuoka Pref. Agric. Exp. Sta. N. $6: 1 \sim 166$.

SHINOHARA, S. 1980. Phenomenon of premature bolting and flower formation physiology in radish and Brassica greens. In Guidebook for development of vegetable horticulture with capable seed production in the monsoon subtropics. Yokendo, Tokyo. pp. 100 102.

SUGE, H. and L. RAPPAPORT 1968. Role of gibberellins in stem elongation and flowering in Japanese radish. Plant Physiol. $43: 1208 \sim 1214$.

SUGE, H. and H. TAKAHASHI 1982. The role of gibberellins in the stem elongation and flowering of Chinese cabbage, Brassica campestris var. pekinensis in their relation to vernalization and phtoperiod. Rep. Inst. Agric. Res. Tohoku Univ. $33: 15 \sim 34$.

SUGIYAMA, N. 1943. On the bolting of several species in Cruciferae vegetables. Jour. Jap. Soc. Hort. Sci. $14: 267 \sim 276$.

YAMASAKI, K. 1956. Thermo-stage for the green plant of Chinese cabbage grown in spring. Bull. Hort. Div. Tokai-Kinki Agric. Exp. Sta. 1:34 47. 
ブラシカ属作物の開花に和ける春化と日長の 役割についての制御環境下での再検討

菅洋

(東北大学農学研究所)

Brassica campestris の 3 変種に属する 7 栽培品種を用いて，その開花に特ける春化と日長の役割をジベレ リンとの関連に执いてファイトトロンを用いて研究した。

供陚 7 品種中 5 種の日本品種（野沢菜，卵月小松菜，新山東菜，晚生真菜，四月しろ菜）は 20 日間種子春化 しても，8時間日長下では花芽分化しなかった。 $\mathrm{GA}_{3}$ 怆これらの植物に茎伸長をひき挔こすが花芽分化させな かった。これらの品種では，GA は抽苔には直接関与しているが，花芽分化には直接的には関与していないるの と結論される。

また，これらの結果より，ブラシカ属野菜の開花に括ける日長の役割を過少評価していた従来の説は訂正を 必要とするものと判断される。

2 種の中国品種は，その開花反応が特異である。菜心は春化要求の小さい中日性品種で，種子春化の有無に かかわらず 24 時間日長下 8 時間日長下ともに開花した。他方, 紅菜苔は, 春化要求は小さいが, 典型的な長日 植物であった。乙かしながら，春化処理は長日要求に代替し，種子春化すると 8 時間日長下でむ開花した。 8 時間日長下の非春化植物に $\mathrm{GA}_{3}$ をやると開花をひき抏こした。一方，種子春化した植物を $\mathrm{GA}$ 生合成阻害剂 のAncymidol で処理すると開花を阻害した。紅菜苔では GA は，茎伸長だけでなく開花それ自体にもなにか 役割を演じていると推定される。 